\title{
Convection Ignition of Live Forest Fuels
}

\author{
SARA MCALLISTER and MARK FINNEY \\ Rocky Mountain Research Station - Missoula Fire Sciences Laboratory \\ USDA Forest Service \\ 5775 W US Highway 10 \\ Missoula, MT 59808
}

\begin{abstract}
Wildland fires are an extremely costly and deadly problem. Crown fires, where live foliage ignites and burns, are particularly unpredictable - in part because live fuel ignition and combustion is poorly understood. Many wildland fire models assume radiation is the controlling heat transfer mechanism. However, there is a growing indication that radiation is insufficient to ignite the small, thin fuel particles that carry a wildland fire and that convective heating and flame bathing is a critical component. Unfortunately, ignition by convection heating of any fuel is poorly understood. Ignition of live forest fuels by any means is also completely unknown due to complicated moisture content and fuel chemistry considerations. To gain some insight into the wildland fire problem, an apparatus was built using two 6.5 $\mathrm{kW}$ electrical heaters to heat gas (air, nitrogen, etc.) over a range of temperatures from ambient up to $1200^{\circ} \mathrm{C}$. The flow rate of these "airtorches" is adjustable. This apparatus was used to convectively ignite a range of both live and dead forest fuels. Fuels from all over the United States where used including Southern California, Utah, Florida, and Montana. To examine ignition threshold conditions and to have distinguishable differences in ignition times, air temperatures of $500^{\circ} \mathrm{C}$ and $600^{\circ} \mathrm{C}$ were used. The airflow rate varied slightly from $1.3 \mathrm{~m} / \mathrm{s}$ to $1.4 \mathrm{~m} / \mathrm{s}$ due to the density difference. Because live forest fuels contain large amounts of water, the evolution of both water and carbon dioxide was measured with time using a differential gas analyzer. Flaming ignition was seen for all dead fuels at $500^{\circ} \mathrm{C}$, but the live fuels mostly showed glowing ignition. At $600^{\circ} \mathrm{C}$, all fuels showed flaming ignition within 1-26 sec. Interestingly, all live fuels were still actively releasing water at ignition, implying there are steep temperature gradients within these physically thin fuels (i.e. not thermally thin). Simple heat transfer analysis in conjunction with the water evolution information was used to help explain the differences in ignition times due to fuel geometry.
\end{abstract}

KEYWORDS: wildfires, ignition, live fuels

\section{NOMENCLATURE LISTING}

$\begin{array}{llll}A_{s} & \text { surface area } & R e & \text { Reynolds number } \\ B i & \text { Biot number } & u & \text { velocity }(\mathrm{m} / \mathrm{s}) \\ c & \text { specific heat } & V & \text { volume }\left(\mathrm{m}^{3}\right) \\ d & \text { diameter }(\mathrm{cm}) & \text { Greek } & \\ D & \text { characteristic dimension } & \rho & \text { density }\left(\mathrm{kg} / \mathrm{m}^{3}\right) \\ h & \text { heat transfer coefficient }\left(\mathrm{W} / \mathrm{m}^{2} \mathrm{k}\right) & v & \text { kinematic viscosity }\left(\mathrm{m}^{2} / \mathrm{s}\right) \\ k & \text { thermal conductivity } & \text { subscripts } \\ M C & \text { moisture content } & \text { conv } & \text { convective } \\ N u & \text { Nusselt number } & d r y & \text { dry property } \\ P r & \text { Prandtl number } & \text { i } & \text { initial } \\ q^{\prime \prime} & \text { heat flux }\left(\mathrm{kW} / \mathrm{m}^{2}\right) & \text { ig } & \text { at ignition } \\ t & \text { time }(\mathrm{s}) & \text { surf } & \text { at surface } \\ T & \text { temperature }(\mathrm{K}) & \infty & \text { free stream value }\end{array}$

\section{INTRODUCTION}

Wildland fires are an extremely costly problem. Crown fires, where live foliage ignites and burns, are particularly dangerous. Many wildland fire models assume radiation is the controlling heat transfer mechanism (such as [1, 2, 3, 4, and 5]). However, there is a growing indication that radiation is insufficient to ignite the small, thin fuel particles that carry a wildland fire. More and more evidence suggests that convective heating and flame bathing is a critical component (for example see [6] and [7]). 
Unfortunately, ignition by convective heating of any fuel is relatively poorly understood as much of the ignition work in the literature has focused on ignition due to radiative heating. In one of the few works found that studied ignition due to pure convective heating, Niioka et al. [8] heated $20 \mathrm{~mm}$ diameter hemispheres of four different polymers (PMMA, PVC, HTPB, and CTPB) in a stagnation point flow. The flow velocity, oxygen fraction, and temperature were varied. It was demonstrated that two regimes exist one controlled by the solid pyrolysis and the other by gas phase kinetics. In the pyrolysis controlled regime, increasing the flow velocity increases the heating rate of the fuel and thus decreases the ignition time. As the flow is further increased, however, the residence time becomes too small compared to the gas phase reaction time (large Damköhler number) and the solid ignition time begins to increase. This means that there is an optimal flow velocity that results in a minimum ignition time. A similar trend of ignition time but with Reynolds number was found by Wang and Yang in their experiments with PMMA [9]. Wang and Yang also noted that the surface temperature at ignition is strongly affected by the Reynolds number (see also [10]). The surface temperature at ignition may also be a function of the air temperature, as suggested by DiBlasi et al. [11]. Though these works have provided some important insights into convective ignition, their scope is still relatively limited. Further work to examine the effects of particle dimensions and shape, charring and glowing combustion, flow regime (stagnation vs. cross flow vs. parallel flow), flow temperature, and gas composition is still needed.

The study of ignition and subsequent flame spread of forest fuels has largely been performed using dried and dead fuels and only a few works were found that examined live fuels $[12,13,14,15,16]$. Dimitrakopoulos and Papaioannou [12], Jervis et al. [13], McAllister et al. [14], all studied ignition due to radiative heating. Xanthopoulos and Wakimoto [16] and Fletcher and coworkers ([15, 17, and 18]) were the only studies found that convectively heated live fuels to ignition. However, the study in [12] was primarily focused on developing an empirical correlation for the ignition time rather than investigating the physical processes involved in ignition. Fletcher and coworkers $([15,17$, and 18$)$ attempted to correlate the ignition time with leaf thickness and moisture content, however, almost no correlation with moisture content and only a slight correlation with leaf thickness were found. Though the heating mechanism was radiation, both Jervis et al. [13] and McAllister et al. [14] also noted a difference in the ignition behavior of live fuels than cannot be solely explained by moisture content. Jervis et al. [13] suggested that volatiles were lost in drying the fuels which contributed to the very different ignition behavior seen between live and dried. McAllister et al. [14] looked to the variation in the chemical composition of the live fuel to help explain the discrepancies. Dead forest fuels are primarily composed of cellulose, lignin, and hemicellulose and their dry weight remains constant. Live fuels, however, can be up to half non-structural carbohydrates like sugars and starches [14]. Because these non-structural carbohydrates are vital for the biological processes of the plant, the amount stored can vary during the growing season and thus the dry weight of the fuel can vary [19]. It is very possible that the apparent moisture content of the fuel can change solely due to changes in the dry weight while the relative amount of water stays constant (see for example [6] and [20]). A still unexplained empirical observation is the "moisture of extinction" [21]. Wildland fires in dead fuels will not spread above some threshold of fuel moisture content, typically assumed to be between 10 and $40 \%$ [21]. However, in crown fires, live fuels with moisture contents well above $70 \%$ are what carry the extremely vigorous fire. Clearly there is a complicated and unknown relation between the chemical composition and moisture content that has a significant effect on the ignition of live fuels.

This work is meant to be a first step towards understanding the complex behavior of the convective ignition of live forest fuels. Here we use hot air at two temperatures $\left(500^{\circ} \mathrm{C}\right.$ and $\left.600^{\circ} \mathrm{C}\right)$ to ignite a wide range of forest fuels, both live and dead. The evolution of water from the fuels during heating and ignition is measured and discussed. The trends of the ignition time are discussed with the aid of simple heat transfer principles.

\section{EXPERIMENT DESCRIPTION}

The convective heating device consists of $2,6.5-\mathrm{kW} \mathrm{MHI}^{1}$ electric "airtorches" mounted horizontally and connected via a ceramic block manifold (see Fig. 1). The manifold combines the two airstreams and directs the flow through a gentle $90^{\circ}$ bend so the outlet is vertically upward. The outlet port of the manifold is

\footnotetext{
${ }^{1}$ The use of trade names is provided for information purposes only and does not constitute endorsement by the U.S. Department of Agriculture.
} 
$15.24 \mathrm{~cm}(6 \mathrm{in})$ in diameter. The airflow rate through the airtorches is adjustable, however a minimum setting of $261 \mathrm{~L} / \mathrm{min}$ per torch is recommended to prevent the torches from overheating. The airflow through the torches is controlled by two Omega FMA-2612A mass flow controllers, and is dried using a desiccant. The temperature of the airtorches is adjustable from ambient up to $1200^{\circ} \mathrm{C}$. Controller units maintain the set point of each airtorch based on temperature measurements from K-type thermocouples located in the immediate outlet of each airtorch (prior to entering the manifold). Unfortunately, there are heat losses in the ceramic manifold, so the reported air temperature is measured using a K-type thermocouple located in the outlet of the manifold. The outlet of the manifold exhausts to the ambient air, and due to entrainment cools rapidly within a few centimeters above the outlet.

All fuels were tested at outlet air temperatures of $500^{\circ} \mathrm{C}$ and $600^{\circ} \mathrm{C}$. For tests performed at $500^{\circ} \mathrm{C}$, the total airflow rate was $546 \mathrm{~L} / \mathrm{min}$. In order to achieve $600^{\circ} \mathrm{C}$ at the outlet and to account for the reduced density, a slightly lower flow rate of $522 \mathrm{~L} / \mathrm{min}$ was used. These flow rates correspond to an airflow velocity of 1.3 $\mathrm{m} / \mathrm{s}$ at $500^{\circ} \mathrm{C}$ and $1.4 \mathrm{~m} / \mathrm{s}$ at $600^{\circ} \mathrm{C}$. A range of fuel samples were tested from dry wood sticks to live fuels from Florida, South Carolina, Southern California, Utah, and Montana. A full list of fuels tested is shown below in Table 1. The cast lodgepole pine needles were collected from the litter layer below the trees and only intact, non-degraded needles were considered (appearing light brown rather than dark grey). Each fuel and temperature combination was tested twice. The moisture content on a dry mass basis of each fuel was determined by either using a Computrac MAX 2000XL or weighing the fuel before and after drying in an oven at $100^{\circ} \mathrm{C}$ for a few days.

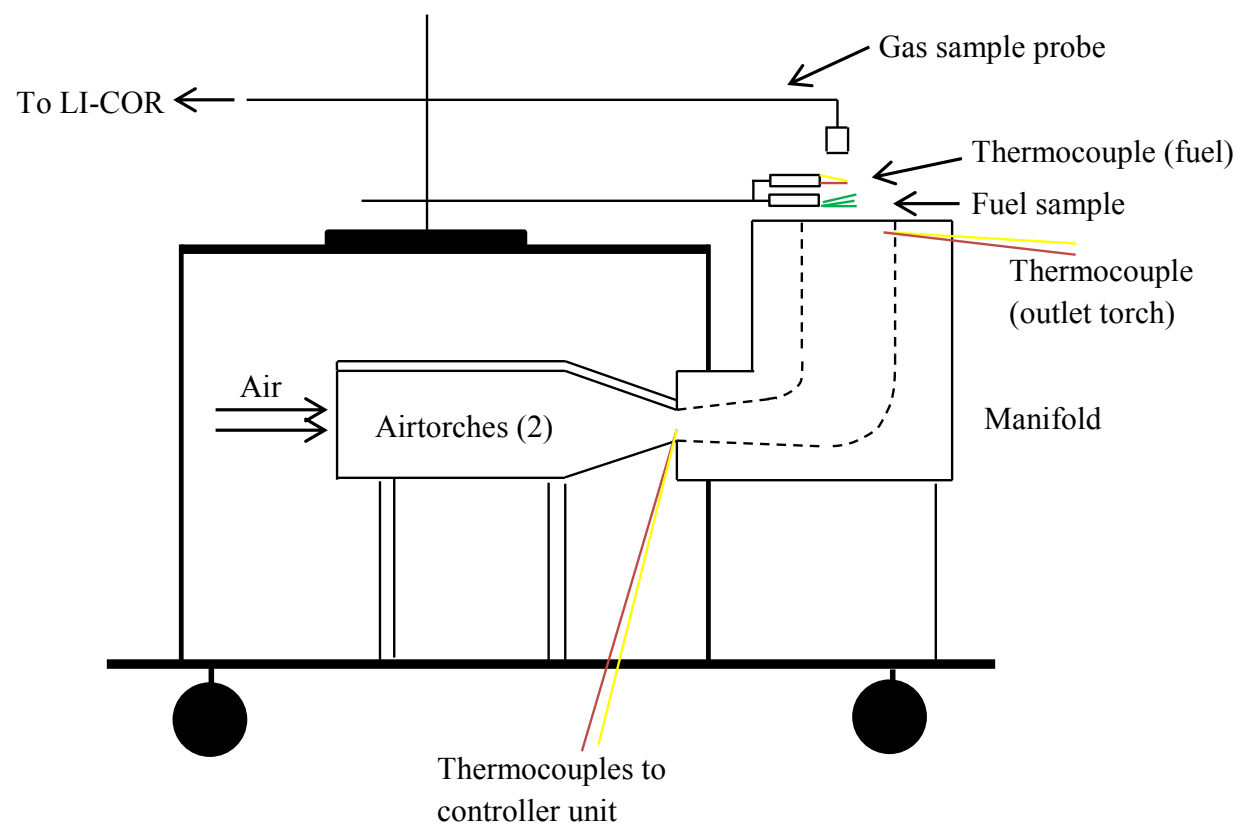

Fig. 1. Schematic of airtorch experiment.

Fuel samples were mounted using $0.6 \mathrm{~cm}$ diameter ceramic tubes that were $15 \mathrm{~cm}$ in length. Clean ceramic tubes were used for each test to avoid contamination. The ceramic tubes were cleaned by baking them overnight in a muffle furnace at $850^{\circ} \mathrm{C}$. For each test, a ceramic tube with fuel sample was mounted onto a sliding mechanism that allowed the fuel to be quickly, easily, and reproducibly placed inside the hot air stream, right at the outlet of the manifold. A $5 \mathrm{mil}(0.13 \mathrm{~mm} / 0.005$ "/36 AWG) K-type thermocouple was mounted $2.2 \mathrm{~cm}$ directly above the fuel sample on the sliding mechanism (see Fig. 1). This temperature measurement helped to bracket the fuel temperature, synchronize the $\mathrm{H}_{2} \mathrm{O}$ and $\mathrm{CO}_{2}$ data with the ignition event, and to aid in the ignition time measurement. All ignition time measurements were made visually and confirmed with the thermocouple data. 
Table 1 - Fuels tested and mounting procedure.

\begin{tabular}{|c|c|c|c|}
\hline Sample description & Source & Dimensions & Mounting \\
\hline $\begin{array}{l}\text { Dry ponderosa pine }(P . \\
\text { ponderosa) stick }\end{array}$ & California & $\begin{array}{l}1.59 \mathrm{~mm}\left(1 / 16^{\prime \prime}\right) \mathrm{x} \\
6 \mathrm{~cm}\end{array}$ & Cotronics paper \\
\hline $\begin{array}{l}\text { Rehydrated ponderosa pine } \\
\text { stick }\end{array}$ & California & $\begin{array}{l}1.59 \mathrm{~mm}\left(1 / 16^{\prime \prime}\right) \mathrm{x} \\
6 \mathrm{~cm}\end{array}$ & Cotronics paper \\
\hline $\begin{array}{l}\text { Green Douglas-fir stem } \\
\text { (Pseudotsuga menziesii) }\end{array}$ & Evaro, Montana & $\begin{array}{l}\sim 1.9 \mathrm{~mm} \times 2.5 \mathrm{~cm} \\
\text { stem }\end{array}$ & Cotronics paper \\
\hline $\begin{array}{l}\text { Dry cast lodgepole pine ( } P \text {. } \\
\text { contorta) (litter) }\end{array}$ & Evaro, Montana & $\begin{array}{l}\sim 0.61 \mathrm{~mm} \times 5 \mathrm{~cm} \\
4 \text { needle clumps }\end{array}$ & Cotronics paper + binder clip \\
\hline $\begin{array}{l}\text { Rehydrated cast lodgepole } \\
\text { pine (litter) }\end{array}$ & Evaro, Montana & $\begin{array}{l}\sim 0.61 \mathrm{~mm} \times 5 \mathrm{~cm} \\
4 \text { needle clumps }\end{array}$ & Cotronics paper + binder clip \\
\hline Dry live lodgepole pine & Evaro, Montana & $\begin{array}{l}\sim 0.61 \mathrm{~mm} \times 5 \mathrm{~cm} \\
4 \text { needle clumps }\end{array}$ & Cotronics paper + binder clip \\
\hline $\begin{array}{l}\text { Rehydrated live lodgepole } \\
\text { pine }\end{array}$ & Evaro, Montana & $\begin{array}{l}\sim 0.61 \mathrm{~mm} \times 5 \mathrm{~cm} \\
4 \text { needle clumps }\end{array}$ & Cotronics paper + binder clip \\
\hline Lodgepole pine & Evaro, Montana & $\begin{array}{l}\sim 0.61 \mathrm{~mm} \times 5 \mathrm{~cm} \\
4 \text { needle clumps }\end{array}$ & Cotronics paper + binder clip \\
\hline Douglas-fir & Evaro, Montana & $\begin{array}{l}\sim 0.51 \mathrm{~mm} \times 2.5 \mathrm{~cm} \\
4 \text { needles }\end{array}$ & Cotronics paper + binder clip \\
\hline $\begin{array}{l}\text { Manzanita (Arctostaphylos } \\
\text { sp.) }\end{array}$ & Riverside, California & $\begin{array}{l}\sim 0.48 \mathrm{~mm} \times \sim 2.5 \\
\mathrm{~cm} \text { x } 5 \mathrm{~cm}, \text { Leaf }\end{array}$ & Cotronics paper \\
\hline Gallberry (Ilex glabra) & $\begin{array}{l}\text { Apalachicola NF, } \\
\text { Sophoppy, Florida }\end{array}$ & $\begin{array}{l}\sim 0.34 \mathrm{~mm} \times \sim 1.5 \\
\mathrm{~cm} \times 5 \mathrm{~cm}, \text { Leaf }\end{array}$ & Cotronics paper \\
\hline $\begin{array}{l}\text { Black titi (Cyrilla } \\
\text { racemiflora) }\end{array}$ & $\begin{array}{l}\text { Apalachicola NF, } \\
\text { Sophoppy, Florida }\end{array}$ & $\begin{array}{l}\sim 0.25 \mathrm{~mm} \mathrm{x} \sim 2 \mathrm{~cm} \\
\mathrm{x} 7 \mathrm{~cm}, \text { Leaf }\end{array}$ & Cotronics paper \\
\hline $\begin{array}{l}\text { Chamise (Adenostoma } \\
\text { fasciculatum) }\end{array}$ & Riverside, California & $\begin{array}{l}\sim 6 \mathrm{~mm} \times 4 \mathrm{~cm} \\
\text { branch tip }\end{array}$ & Cotronics paper \\
\hline $\begin{array}{l}\text { Sagebrush (Artemisia } \\
\text { tridentate) }\end{array}$ & Provo, Utah & $\begin{array}{l}\sim 15 \mathrm{~mm} \times 4 \mathrm{~cm} \\
\text { branch tip }\end{array}$ & Cotronics paper \\
\hline Wiregrass (Aristida stricta) & $\begin{array}{l}\text { Coastal South } \\
\text { Carolina }\end{array}$ & $\begin{array}{l}\sim 0.4 \mathrm{~mm} \times 6 \mathrm{~cm} \\
6 \text { pieces }\end{array}$ & Cotronics paper + binder clip \\
\hline
\end{tabular}

Also listed in Table 1 is a description of how each fuel was mounted onto the ceramic tube. For the needles, four individual needles (Douglas-fir) or needle pairs (lodgepole pine) were held using a $2 \mathrm{~cm}$ binder clip lined inside and out with Cotronics paper. The binder clip was mounted into the ceramic tube via a $4 \mathrm{~cm}$ screw drilled through the wide part of the clip. Samples comprised of leaves and stems were mounted into the ceramic tube by wrapping the end of the fuel with a $0.5 \mathrm{~cm}$ strip of Cotronics paper to both insulate the fuel and hold it into place.

$\mathrm{H}_{2} \mathrm{O}$ and $\mathrm{CO}_{2}$ concentrations of the evolved products were measured using a LI-COR LI-7000 differential gas analyzer. One of the advantages of using a hot air stream as a source of convective heating is that it provides a relatively clean background for the LI-COR (as opposed to a gas burner). A stainless steel gas sampling probe was fixed in the hot airstream $6 \mathrm{~cm}$ above the fuel sample. The sampling probe had a 2.5 $\mathrm{cm}$ diameter, $3 \mathrm{~cm}$ long cylindrical collar to trap as much of the gasses released from the fuel sample as possible. The LI-COR and pump drew the gas sample through the probe at $2.5 \mathrm{~L} / \mathrm{min}$. The sample line 
was wrapped in heat tape to maintain a line temperature of $\sim 100^{\circ} \mathrm{C}$. This was monitored with a thermocouple placed directly on the steel tube, under the heat tape. The LI-COR analyzed the gas stream for $\mathrm{H}_{2} \mathrm{O}$ and $\mathrm{CO}_{2}$ at a rate of $10 \mathrm{~Hz}$. The LI-COR data were logged using a Campbell Scientific CR3000, along with the temperature measurements made just above the fuel sample ("fuel temperature"), outlet of the manifold ("torch temperature"), and along the gas sample line ("probe temperature").

\section{SIMPLE HEAT TRANSFER ANALYSIS}

Because most, if not all, of the thermal properties of live forest fuels are completely unknown, a complete heat transfer and ignition model cannot be performed at this time. Instead, some of the relevant heat transfer relations will be suggested as to their possible role in explaining the experimental results. A quick summary is provided here.

All of the fuels tested have very different shapes and sizes, thus the Nusselt numbers and convective heat transfer coefficients will vary from fuel to fuel. There are three categories of fuels tested: leaves, needles, and sticks. In order to simplify the discussion as much as possible (and because there simply aren't any more appropriate relations), the leaves will be treated as a flat plate in a cross flow and both the needles and sticks as circular cylinders in a cross flow. For the needles and sticks, the average Nusselt number over a very wide range of Reynolds numbers is given by the Churchill and Bernstein relation [22]

$$
\overline{N u}_{D}=0.3+\frac{0.62 \operatorname{Re}_{D}^{1 / 2} \operatorname{Pr}^{1 / 3}}{\left[1+(0.4 / \operatorname{Pr})^{2 / 3}\right]^{1 / 4}}
$$

where the Reynolds number for a characteristic diameter is

$$
\operatorname{Re}_{D}=\frac{u_{\infty} D}{v}
$$

Because the temperature of the air is so high, the kinematic viscosity is also high $\left(80.31 \times 10^{-6} \mathrm{~m}^{2} / \mathrm{s}\right.$ at 500 ${ }^{\circ} \mathrm{C}$ to $97.99 \times 10^{-6} \mathrm{~m}^{2} / \mathrm{s}$ at $600^{\circ} \mathrm{C}$ ). Combined with the small diameters of these fuels, the Reynolds numbers tend to be quite low (see Table 2). Unfortunately, no Nusselt number correlation was found in the literature for a flat plate in cross flow that is valid for this range of Reynolds numbers. Because this analysis is purely meant to be qualitative, our discussion will make use of the relation derived by Hilpert $[23,24]$ (with the correct values of the constants from [25])

$$
\overline{N u_{D}}=0.231 \operatorname{Re}_{D}^{0.731}
$$

while keeping in mind that this correlation is valid only for Reynolds numbers in the range of $6 \times 10^{3}$ to 2.4 $\mathrm{x} 10^{4}$. Table 2 lists some approximate values of the Reynolds number, Nusselt number, and convective heat transfer coefficient (h) for each fuel tested. It is important to remember that the heating rate of the fuel is not uniform over the fuel surface. The heat transfer coefficients and calculated heat fluxes are average values and that, due to the nature of the flow around the fuel particles, there will be regions that experience both significantly higher and lower values (for example at the stagnation point versus the lee side). Additionally, average fuel diameters and thicknesses were used, so there will also be some variability along the length of the fuel due to tapering and widening of the fuel along its length.

Another important piece of the puzzle is the fuel temperature in response to the convective heating. The two extreme models of transient heat conduction are the lumped capacitance model (thermally thin) and the semi-infinite solid model (thermally thick). For simplicity, the time to reach an assumed ignition temperature $\left(\mathrm{T}_{\mathrm{ig}}\right)$ for both of these models will assume only convective heating with a constant convective heat transfer coefficient and constant material properties. From [24] for example, for the lumped capacitance model, the ignition time is given by 


$$
t_{i g}=\frac{\rho K_{C}}{h A_{s}} \ln \left(\frac{T_{i}-T_{\infty}}{T_{i g}-T_{\infty}}\right)
$$

and for the semi-infinite solid (where only the surface reaches the ignition temperature), the ignition time can be found from

$$
\frac{T_{i g, \text { surf }}-T_{i}}{T_{\infty}-T_{i}}=1-\exp \left(\frac{h^{2} \alpha t_{i g}}{k^{2}}\right) \operatorname{erfc}\left(1+\frac{h \sqrt{\alpha t_{i g}}}{k}\right)
$$

Table 2a. Convective heat transfer approximations for air temperature of $500^{\circ} \mathrm{C} . \mathrm{LP}=$ lodgepole pine.

Char.

Thick-

D $\quad \mathrm{h} \quad \mathrm{q}^{\prime \prime}{ }_{\text {conv }}$ ness $\mathrm{Bi} \quad \mathrm{Bi}$

$\begin{array}{lllllll}(\mathrm{cm}) & \mathrm{Re} & \mathrm{Nu} & \left(\mathrm{W} / \mathrm{m}^{2} \mathrm{~K}\right) & \left(\mathrm{kW} / \mathrm{m}^{2}\right) & (\mathrm{mm}) \quad\left(\mathrm{k}_{\text {wood }}\right) \quad\left(\mathrm{k}_{\text {water }}\right)\end{array}$

\begin{tabular}{l|l|l|l|l|l|l|l|l|}
\hline Dry p. pine stick & 0.159 & 25.7 & 3.60 & 97.4 & 45.8 & 1.59 & 1.55 & NA \\
Rehydrated p. pine stick & 0.159 & 25.7 & 3.60 & 97.4 & 45.8 & 1.59 & 1.41 & NA \\
Green Doug-fir stems & 0.19 & 30.8 & 3.91 & 88.5 & 41.6 & 1.9 & 1.53 & 0.25 \\
Dry cast LP & 0.061 & 9.9 & 2.34 & 165.1 & 77.6 & 0.61 & 0.92 & NA \\
Rehydrated cast LP & 0.061 & 9.9 & 2.34 & 165.1 & 77.6 & 0.61 & 0.92 & 0.15 \\
Dry live LP & 0.061 & 9.9 & 2.34 & 165.1 & 77.6 & 0.61 & 0.92 & NA \\
Rehydrated live LP & 0.061 & 9.9 & 2.34 & 165.1 & 77.6 & 0.61 & 0.92 & 0.15 \\
Lodgepole pine & 0.061 & 9.9 & 2.34 & 165.1 & 77.6 & 0.61 & 0.92 & 0.15 \\
Douglas-fir & 0.051 & 8.3 & 2.17 & 182.7 & 85.9 & 0.51 & 0.85 & 0.14 \\
Manzanita & 4 & 648 & 40.93 & 44.0 & 20.7 & 0.48 & 0.19 & 0.03 \\
Gallberry & 4.5 & 728 & 44.61 & 42.6 & 20.0 & 0.34 & 0.13 & 0.02 \\
Black Titi & 7 & 1133 & 61.62 & 37.9 & 17.8 & 0.25 & 0.09 & 0.01 \\
Chamise & 0.6 & 97 & 6.74 & 48.3 & 22.7 & 0.74 & 0.33 & 0.05 \\
Sagebrush & 1.5 & 243 & 10.55 & 30.2 & 14.2 & 0.28 & 0.08 & 0.01 \\
Wiregrass & 0.04 & 6.5 & 1.95 & 209.9 & 98.7 & 0.04 & 0.08 & NA
\end{tabular}

The heat losses from reradiation have been ignored in the above equations. If an ignition temperature of $350^{\circ} \mathrm{C}$ and emissivity of 0.7 are assumed, the reradiation heat flux is at most about $5.5 \mathrm{~kW} / \mathrm{m}^{2}$. The Biot number $(\mathrm{Bi}=\mathrm{hL} / \mathrm{k})$ is often used to determine the appropriateness of the above models. Table 2 shows the possible range of Biot numbers for the fuels tested. Because the thermal conductivity is unknown, the Biot number is calculated using both the thermal conductivity of dry wood $(0.10 \mathrm{~W} / \mathrm{mK}$ [26]) and of pure water at $100^{\circ} \mathrm{C}(0.68 \mathrm{~W} / \mathrm{mK})$. The leaf thickness is used here for the characteristic length of both the leaves and the chamise and sagebrush branch tips.

To include the effect of the moisture content on the ignition time, Babrauskas [10] suggests merely adding a term to the dry ignition time that accounts for the time it takes to partially dry the material: 
$t_{i g}=t_{i g, d r y}+\frac{a d \rho_{d r y} M C}{\alpha_{S} \dot{q}_{e}^{\prime \prime}}$

where $a=33,200\left(\dot{q}_{e}^{\prime \prime}\right)^{-2}-8.7$. While this relation was developed for radiant heating of dead fuels, it is mentioned as a discussion point.

Table $2 \mathrm{~b}$. Convective heat transfer approximations for air temperature of $600^{\circ} \mathrm{C}$. $\mathrm{LP}=$ lodgepole pine.

Char.

Thick

$\mathrm{D} \quad \mathrm{h} \quad \mathrm{q}^{\prime \prime}$ conv $\quad$-ness

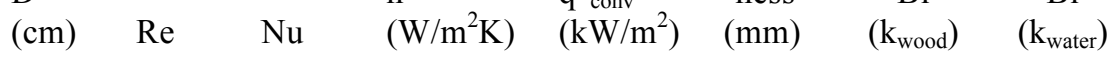

\begin{tabular}{l|l|l|l|l|l|l|l|l|}
\hline Dry p. pine stick & 0.159 & 22.7 & 3.48 & 100.9 & 57.5 & 1.59 & 1.60 & NA \\
Rehydrated p. pine stick & 0.159 & 22.7 & 3.48 & 100.9 & 57.5 & 1.59 & 1.46 & NA \\
Green Doug-fir stems & 0.19 & 27.1 & 3.78 & 91.6 & 52.2 & 1.9 & 1.58 & 0.26 \\
Dry cast LP & 0.061 & 8.7 & 2.27 & 171.2 & 97.6 & 0.61 & 0.95 & NA \\
Rehydrated cast LP & 0.061 & 8.7 & 2.27 & 171.2 & 97.6 & 0.61 & 0.95 & 0.15 \\
Dry live LP & 0.061 & 8.7 & 2.27 & 171.2 & 97.6 & 0.61 & 0.95 & NA \\
Rehydrated live LP & 0.061 & 8.7 & 2.27 & 171.2 & 97.6 & 0.61 & 0.95 & 0.15 \\
Lodgepole pine & 0.061 & 8.7 & 2.27 & 171.2 & 97.6 & 0.61 & 0.95 & 0.15 \\
Douglas-fir & 0.051 & 7.3 & 2.10 & 189.6 & 108.0 & 0.51 & 0.88 & 0.14 \\
Manzanita & 4 & 572 & 38.74 & 41.7 & 23.7 & 0.48 & 0.18 & 0.03 \\
Gallberry & 4.5 & 643 & 42.22 & 40.4 & 23.0 & 0.34 & 0.12 & 0.02 \\
Black Titi & 7 & 1000 & 58.32 & 35.8 & 20.4 & 0.25 & 0.08 & 0.01 \\
Chamise & 0.6 & 85.7 & 6.51 & 46.6 & 26.6 & 0.74 & 0.31 & 0.05 \\
Sagebrush & 1.5 & 214 & 10.17 & 29.2 & 16.6 & 0.28 & 0.07 & 0.01 \\
Wiregrass & 0.04 & 5.7 & 1.89 & 203.5 & 116.0 & 0.04 & 0.07 & NA
\end{tabular}

The thermal properties of the fuels will clearly have a large role in the ignition time. As previously stated, however, they are entirely unknown for live forest fuels. While there are some values available in the literature for oven dried fuels, the variation of these properties with moisture content is unknown. There are relations available for the variation in specific heat, density, and thermal conductivity of wood [26]. These relations were used to calculate the Biot number for the rehydrated wood sticks in Table 2.

$\rho=\rho_{d r y}(1+M C / 100)$

$k=\left(\rho_{\text {dry }} / \rho_{\text {water }}\right)(0.1941+0.004064 M C)+0.01864$

$c=\frac{\left(c_{d r y}+c_{\text {water }} M C / 100\right)}{(1+M C / 100)}+M C\left(-0.06191+2.36 \times 10^{-4} T-1.33 \times 10^{-4} M C\right)$

where $\mathrm{T}$ is in Kelvin. These must be taken very cautiously, as they are valid only for dead wood with very different internal structure, and for the specific heat and conductivity, only up to the fiber saturation point (i.e. $\mathrm{MC} \leq 25 \%$ (live fuels can have MCs well over 100\%)). 


\section{RESULTS AND DICSUSSION}

Before the quantitative results are discussed, there are some visual observations made during the tests that are worth noting. Almost all of the live fuels made audible popping and crackling noises while heating, but none of the dry or rehydrated fuels did. The only live fuel that did not make these noises while heating was the sagebrush. This behavior has been noted by others $[15,17,18]$ and it is speculated that the noises are due to the sudden bursting of cell walls and expulsion of water. Unlike dead fuels, live fuels can store large amounts of water within the cells themselves which are like balloons that can expand up to a certain point. Once the pressure inside the cell is too great, the walls burst. In fact, all of the leafy fuels tested developed large blisters on the surface (see Fig. 2). Sagebrush was the only live species tested that didn't have a distinctive waxy coating on the outside of the leaves. It's possible that the cell walls of the sagebrush are much more permeable so that the pressure inside the cells doesn't build during heating. The moisture release would then be more of a diffusive process than an explosive one. A similar trend was noted by others $([15,17,18])$ and when heating green grasses in some early scoping tests.
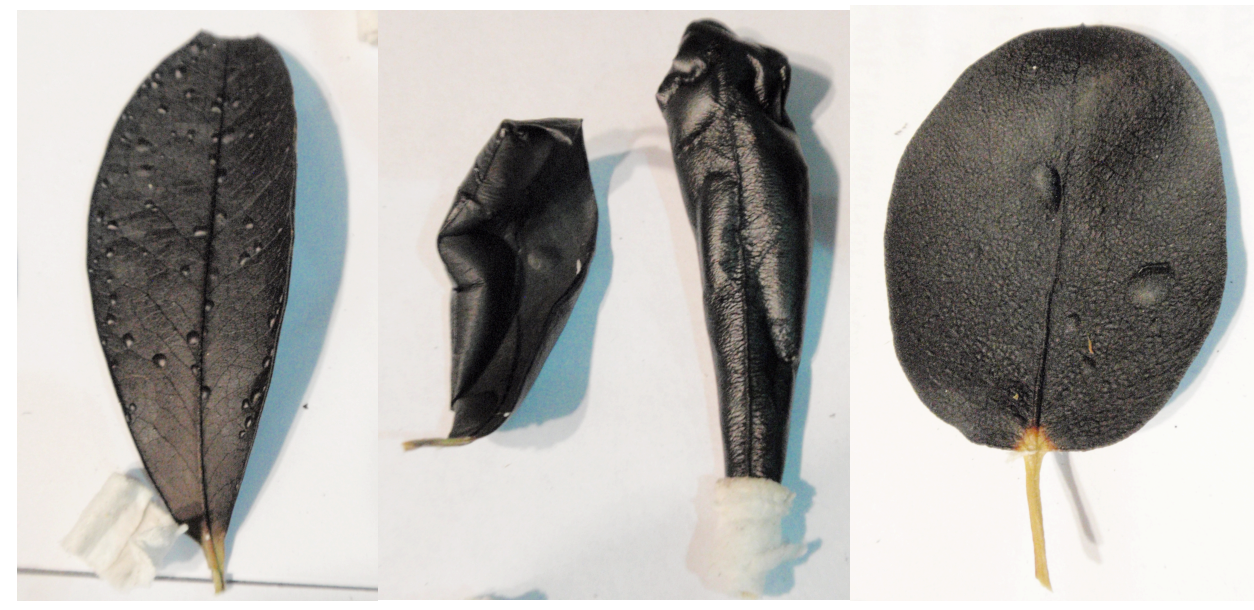

Fig. 2. Bubbles and blisters on live fuels. Left and Center: Gallberry. Right: Manzanita.

Another intriguing visual observation was that most of the live fuels had tiny bright sparks downstream immediately after initiating the heating. The manzanita leaves also released visible white puffs of gas before ignition. These sparks and flashes tended to corresponding to the audible popping noises. It is possible that more than just water is released during these explosive events, such as cell contents (sugars and starches) and cell walls.

Many of the live fuels and the thicker dry wood sticks experienced localized glowing combustion before flaming ignition occurred. This glowing often occurred at the tips of the fuel where it is the thinnest. The glowing then served as a pilot for the flaming ignition. 

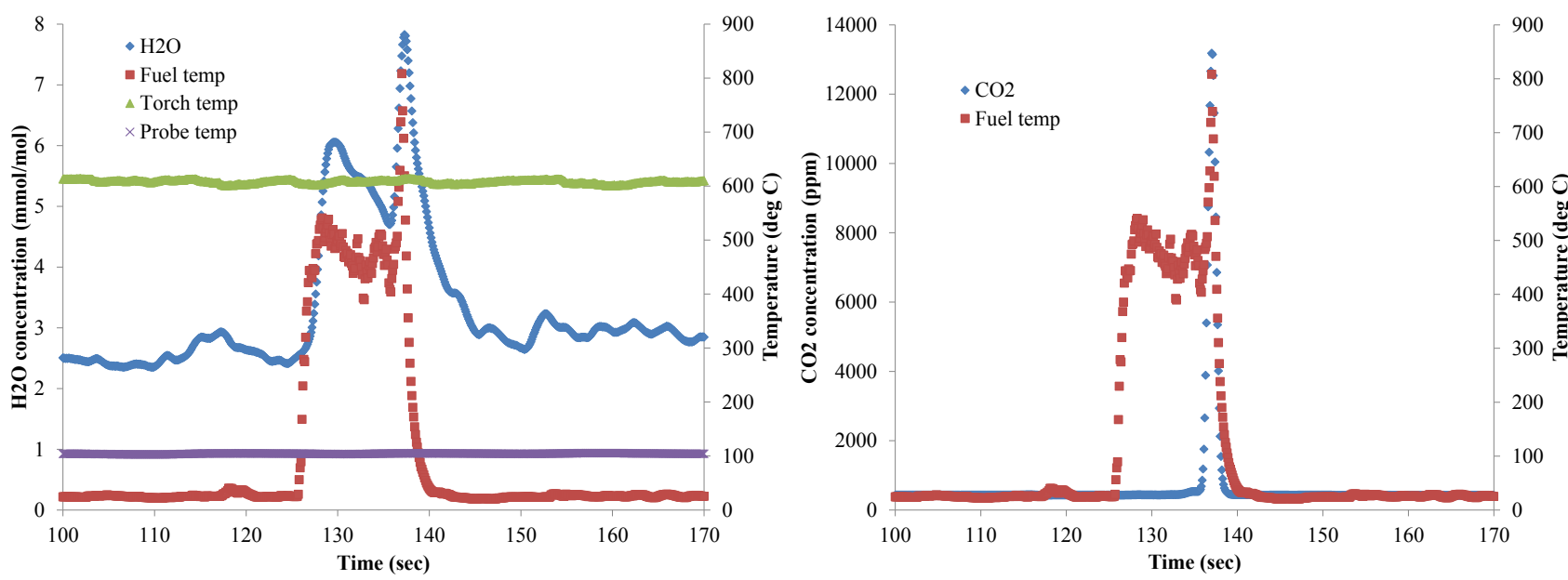

Fig. 3. Evolved $\mathrm{H}_{2} \mathrm{O}$ and $\mathrm{CO}_{2}$ from lodgepole pine needles at $600^{\circ} \mathrm{C}$.
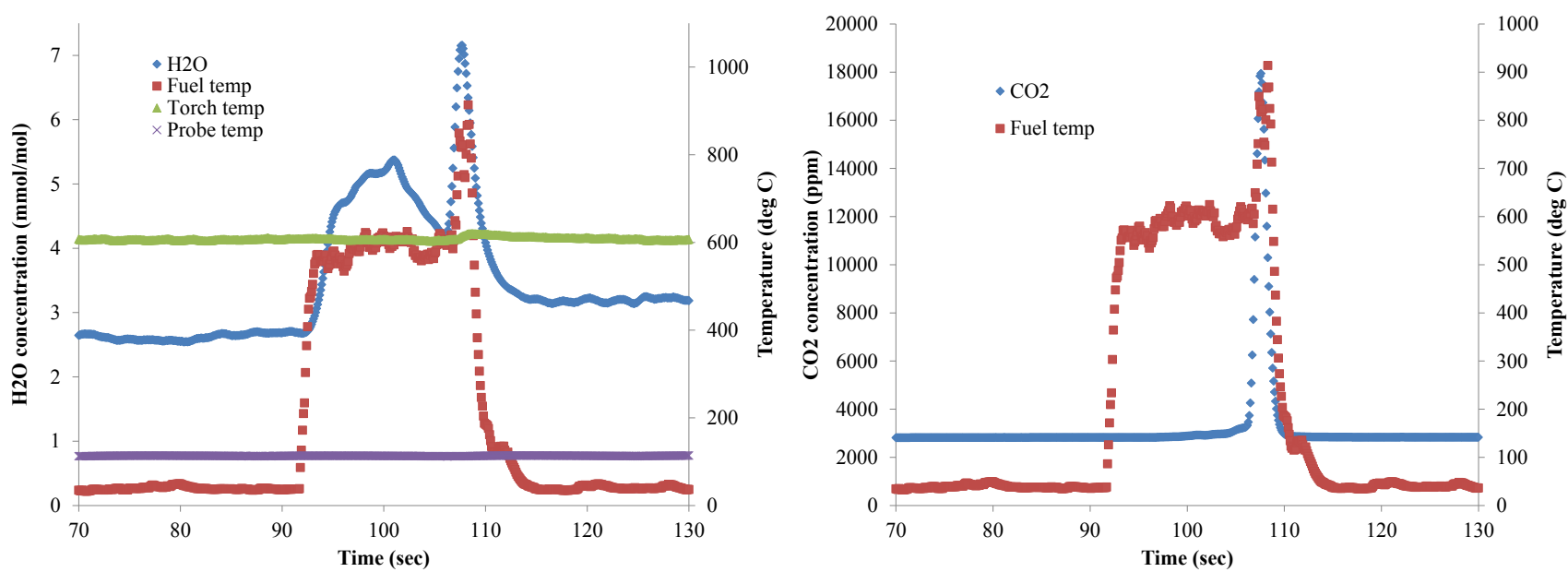

Fig. 4. Evolved $\mathrm{H}_{2} \mathrm{O}$ and $\mathrm{CO}_{2}$ from a manzanita leaf at $600^{\circ} \mathrm{C}$.
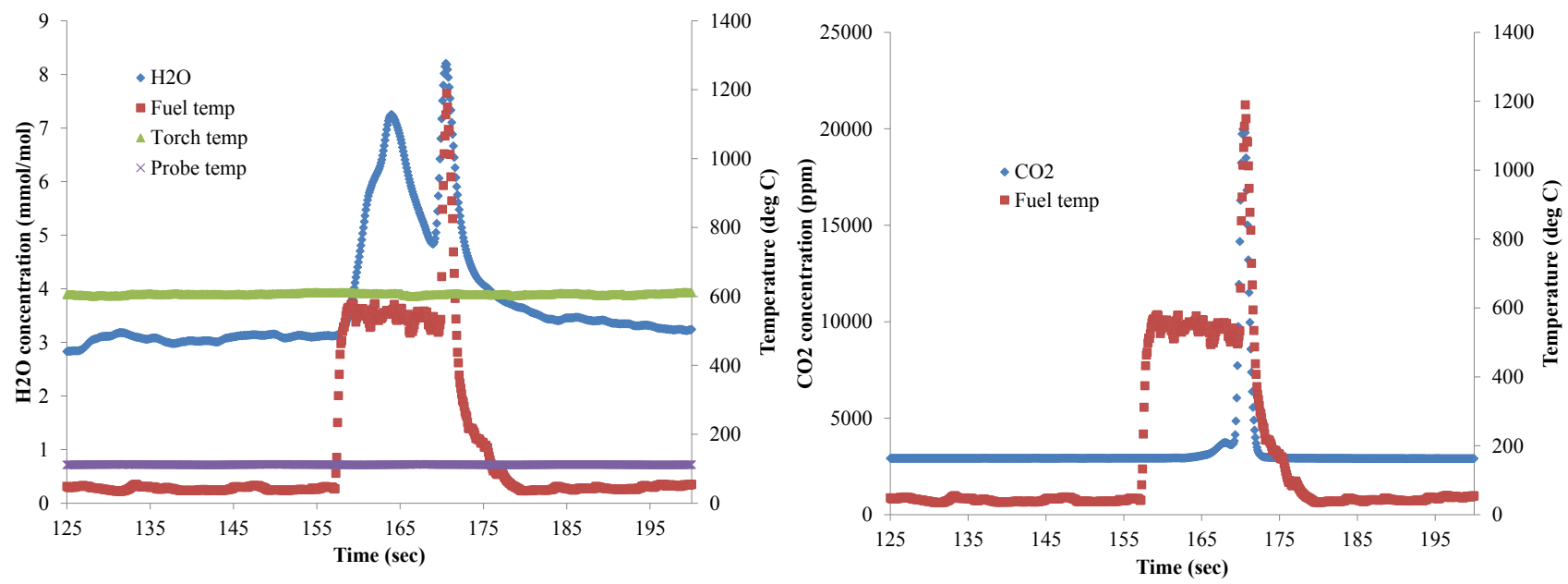

Fig. 5. Evolved $\mathrm{H}_{2} \mathrm{O}$ and $\mathrm{CO}_{2}$ from a gallberry leaf at $600^{\circ} \mathrm{C}$. 

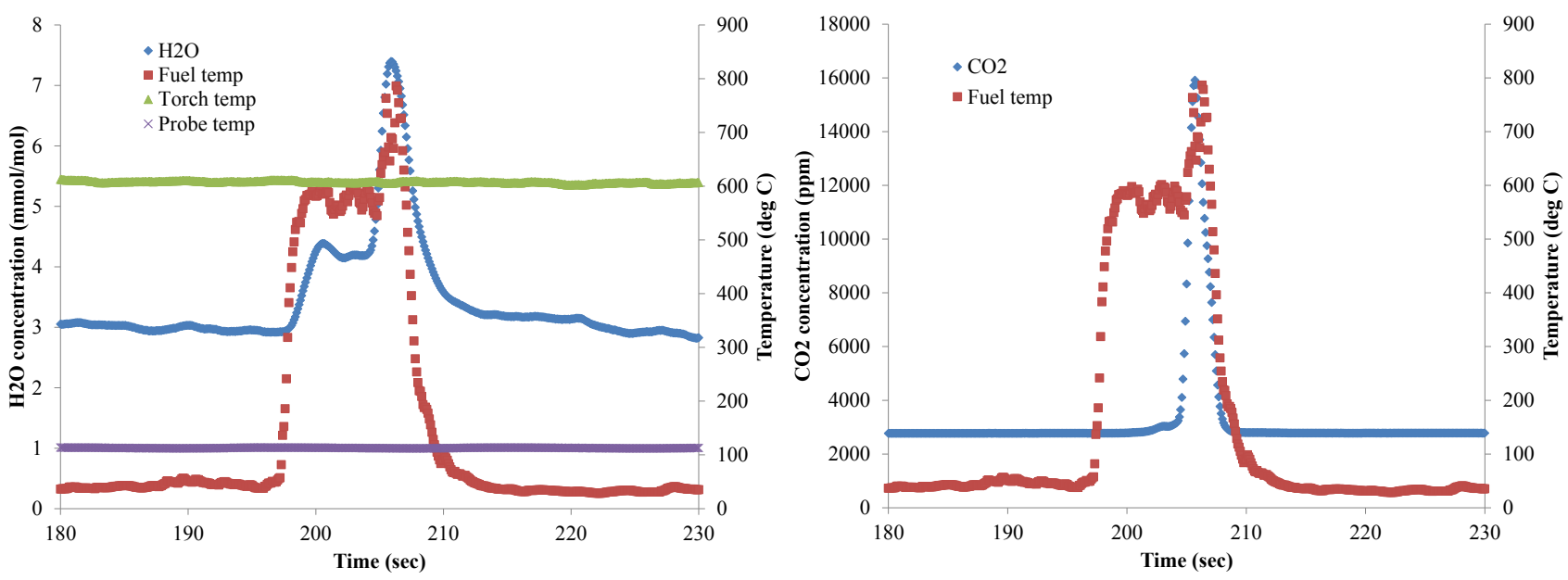

Fig. 6. Evolved $\mathrm{H}_{2} \mathrm{O}$ and $\mathrm{CO}_{2}$ from a chamise branch tip at $600^{\circ} \mathrm{C}$.
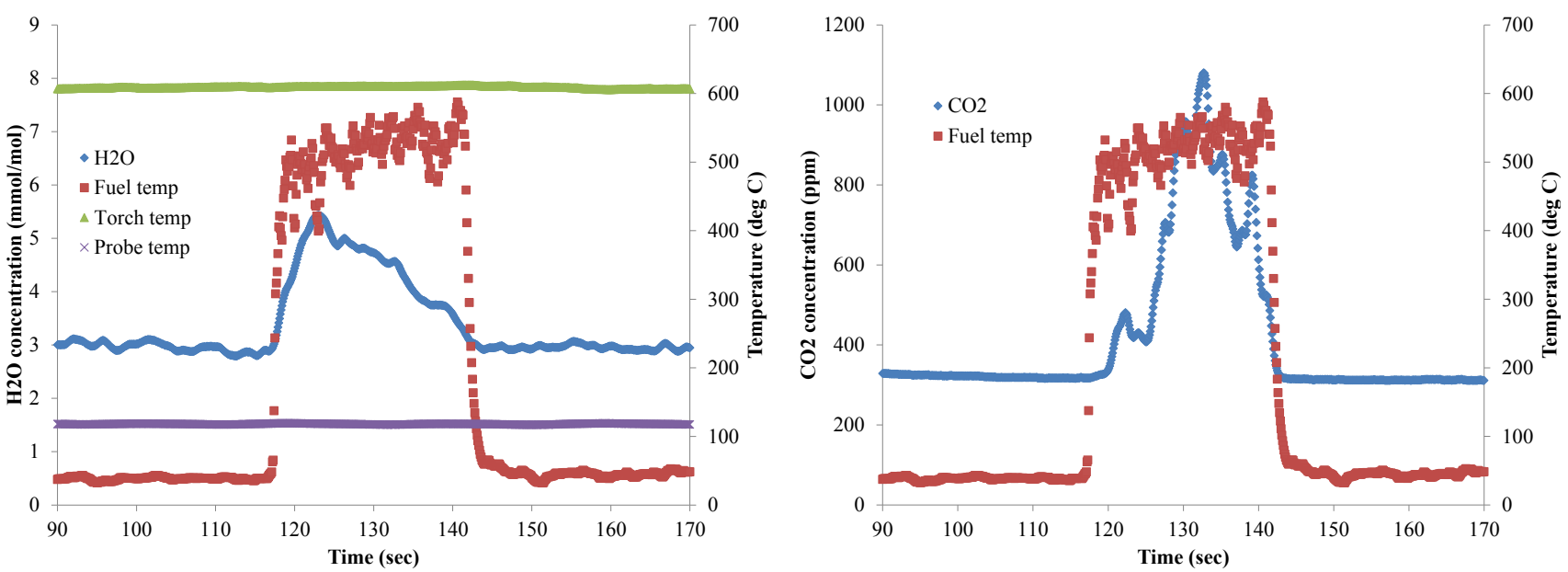

Fig. 7. Evolved $\mathrm{H}_{2} \mathrm{O}$ and $\mathrm{CO}_{2}$ from a sagebrush branch tip at $600^{\circ} \mathrm{C}$ (no ignition).

To gain some insight into how and when water is driven off relative to ignition, the $\mathrm{H}_{2} \mathrm{O}$ and $\mathrm{CO}_{2}$ concentrations were measured. Figs. 3-7 show the typical trends seen for lodgepole pine needles, manzanita leaves, gallberry leaves, chamise branch tips, and sagebrush branch tips at $600^{\circ} \mathrm{C}$. The $\mathrm{H}_{2} \mathrm{O}$ and $\mathrm{CO}_{2}$ measurements were time shifted to account for the lag due to the long sample tube length (about 3 seconds). Also shown in these plots are the air temperatures measured just above the fuel ("fuel temperature") and at the outlet of the torch ("torch temperature") along with the temperature of the gas sampling probe ("probe temperature"). It is important to remember that, despite its name, the fuel temperature is not the actual fuel temperature, but the temperature of the air above. In all cases, the water concentration sharply increases when the fuel is first heated, and then begins to slowly decrease until ignition. At ignition, a sharp increase in the water and carbon dioxide concentrations occurs that coincides with the sharp increase in "fuel" temperature.

From Figs. 3-7, it is clear that all live fuels are still evolving water at the time of ignition. This is particularly noticeable with the chamise branch tips where the concentration of water in the products stays relatively constant just prior to ignition. In all fuels tested, it is possible that the sharp increase in water concentration at ignition includes both water due to combustion but also the remaining free water in the fuel. Even though the Biot numbers in Table 2 indicate that many of these fuels, including the chamise, nearly satisfy the criteria for the lumped capacitance model, the continuing release of moisture indicates 
that there are still large temperature gradients within even the thinnest fuels. Figure 7 shows the no ignition case of sagebrush. Notice that there is only one peak in the water concentration as the fuel is first heated, and no subsequent second peak and no corresponding peak in the "fuel" temperature and $\mathrm{CO}_{2}$ concentration that would indicate flaming ignition. Though the concentrations are much lower, $\mathrm{CO}_{2}$ is still produced during heating, indicating the presence of glowing combustion.

Average moisture contents and ignition times for torch temperatures of both $500^{\circ} \mathrm{C}$ and $600^{\circ} \mathrm{C}$ are shown below in Table 3.

Table 3. Moisture content and ignition times. $\mathrm{NI}=$ no ignition, $\mathrm{NT}=$ not tested, and $\mathrm{LP}=$ lodgepole pine.

\begin{tabular}{|c|c|c|c|c|c|c|c|}
\hline & \multicolumn{4}{|c|}{$500^{\circ} \mathrm{C}$} & \multicolumn{3}{|c|}{$600^{\circ} \mathrm{C}$} \\
\hline & $\begin{array}{l}\text { MC } \\
(\%)\end{array}$ & $\begin{array}{c}\mathrm{t}_{\mathrm{ig}}(\mathrm{s})- \\
\# 1\end{array}$ & $\begin{array}{c}\mathrm{t}_{\mathrm{ig}}(\mathrm{s})- \\
\quad \# 2\end{array}$ & $\begin{array}{c}\mathrm{t}_{\mathrm{ig}}(\mathrm{s})- \\
\text { ave }\end{array}$ & $\begin{array}{c}\mathrm{t}_{\mathrm{ig}}(\mathrm{s})- \\
\quad \# 1\end{array}$ & $\begin{array}{c}\mathrm{t}_{\mathrm{ig}}(\mathrm{s})- \\
\quad \# 2\end{array}$ & $\begin{array}{c}\mathrm{t}_{\mathrm{ig}}(\mathrm{s})- \\
\text { ave }\end{array}$ \\
\hline Dry p. pine stick & 0 & 19.8 & 17.9 & 18.85 & 7.5 & 5.8 & 6.65 \\
\hline Rehydrated p. pine stick & 6 & 28.7 & 16.7 & 22.70 & 5.4 & 6.9 & 6.15 \\
\hline Green Doug-fir stems & 83.0 & char & char & NI & 25.3 & 28.8 & 27.05 \\
\hline Dry cast LP & 0 & 5.7 & 5.4 & 5.55 & 2.6 & 1.3 & 1.95 \\
\hline Rehydrated cast LP & 8 & 8.7 & 7.6 & 8.15 & 1.6 & 2.7 & 2.15 \\
\hline Dry live LP & 0 & glowing & 6.7 & 6.70 & 1.4 & 3.5 & 2.45 \\
\hline Rehydrated live LP & 9 & 15.5 & glowing & 15.50 & 3.7 & 2.2 & 2.95 \\
\hline Lodgepole pine & 133.9 & 16.9 & 12.7 & 14.80 & 11.2 & 10.2 & 10.70 \\
\hline Douglas-fir & 143.1 & glowing & glowing & NI & glowing & 11.9 & 11.90 \\
\hline Manzanita & 97.0 & glowing & glowing & NI & 14.6 & 10.8 & 12.70 \\
\hline Gallberry & 129.0 & char & char & NI & 10.5 & 12.8 & 11.65 \\
\hline Black Titi & 141.0 & glowing & glowing & NI & 10.3 & 7.5 & 8.90 \\
\hline Chamise & 58.6 & 51.1 & 34.6 & 42.85 & 8.8 & 7.2 & 8.00 \\
\hline Sagebrush & 107.3 & glowing & glowing & NI & 20.2 & glowing & 20.20 \\
\hline Wiregrass & 5.1 & 1.3 & 1.7 & 1.50 & NT & NT & NT \\
\hline
\end{tabular}

The dry and rehydrated pine wood sticks ignited at both temperatures tested. At $500^{\circ} \mathrm{C}$, the rehydrated sticks with the $6 \%$ moisture content had a longer ignition time compared to the dry sticks as expected from Eq. 5 above. However, that trend is reversed at $600^{\circ} \mathrm{C}$ and the rehydrated stick actually ignited slightly faster than the dry stick. The "green" Douglas-fir stems had a much higher moisture content (higher than the fiber saturation point of dead wood) and did not ignite at all at $500^{\circ} \mathrm{C}$. At $600^{\circ} \mathrm{C}$, the stems took over three times longer than the ponderosa pine sticks to ignite. In addition to the large increase in moisture content between the dry sticks and the green stems, there are some geometric differences that influence the heat transfer and subsequent temperature rise. As seen in Table 2, the difference in fuel diameter results in a difference in the convective transfer coefficient of about $10 \%$. As indicted in the Biot numbers, the dry sticks are more of a thermally intermediate solid, but because of the high moisture content and resulting high thermal conductivity, the stems could be more closely considered a thermally thin solid which will affect the way in which the solid heats up.

In comparing the ignition time of the dried "live" lodgepole needles to the dried cast needles, there is a very slight difference in ignition times. This could be natural variability in the experiment, but could also be due to the difference in needle composition between cast and live needles. As discussed earlier, non-structural 
carbohydrates (such as sugars and starches) can constitute up to $50 \%$ of live needle mass [14]. Normally, the tree removes these valuable carbohydrates so that the cast needles are primarily structural carbohydrates (cellulose, hemicellulose, and lignin). The dried live needles would have retained these carbohydrates. Another interesting observation is that one sample of the dried live needles didn't have a flaming ignition at $500^{\circ} \mathrm{C}$ but showed glowing combustion. This suggests that the composition of the needles can vary from needle to needle. Because only four needle clumps were burned at a time, variations of the needle chemistry may have an influence on the ignition behavior.

The difference between the live and cast needles was much more apparent when rehydrated to 8-9\%. Even though both live and cast needles were dried completely then rehydrated at the same temperature and relative humidity $\left(35^{\circ} \mathrm{C}\right.$ and $\left.65 \% \mathrm{RH}\right)$, the resulting moisture content was slightly different due to hysteresis effects and the presence of waxy coatings [27]. Though the difference in moisture content was only $1 \%$, the ignition behavior at $500^{\circ} \mathrm{C}$ was markedly different. The cast needles readily ignited whereas the live needles took twice as long or didn't ignite at all. As discussed above, this suggests that the difference in chemical composition of the live versus dead needles can be influencing the ignition.

Interestingly, the only live fuels that ignited at $500^{\circ} \mathrm{C}$ were the lodgepole pine needles and the chamise branch tips. All other live fuels exhibited glowing combustion until the entire fuel sample was consumed, or in the case of the gallberry leaf, merely charred. The live lodgepole needles even ignited as fast or faster than the rehydrated needles with substantially lower moisture contents $(9 \% \mathrm{MC})$. At $600^{\circ} \mathrm{C}$, all of the live fuels ignited. The decrease in ignition time as the temperature was increased was much more pronounced with the rehydrated live needles than with the fresh live needles. The rehydrated live needles ignited 5 times faster while the fresh live needles only ignited about 1.3 times faster. Clearly there are significant differences in the thermal properties of fresh and rehydrated fuels and also the way the live fuels store water.

At $600^{\circ} \mathrm{C}$, the needles ignited much faster than the leaves. As shown in Table 2, the needles have a much higher convective heating rate than the leaves so this is no surprise. What is surprising is the leaf ignition time trend. Manzanita had the highest heat transfer coefficient and the lowest moisture content of the leaves, and yet had the longest ignition time. Conversely, black titi had the lowest heat transfer coefficient and high moisture content, yet had the shortest ignition time. As shown in Table 2, all leaves are thin enough to more closely follow the lumped capacitance model which implies that the ignition time is proportional to the leaf thickness (Eq. 3). The Black titi leaves were about half as thick as the manzanita leaves which helps explain how a leaf with such high moisture content can ignite more quickly.

Because the sagebrush branch tips were full and dense, the characteristic diameter when calculating the Reynolds and Nusselt numbers is much larger than the other cylindrical fuels. This means that the heat transfer coefficient and thus the convective heating rate is much lower, contributing to a long ignition time. However, the chamise also had a similar low convective heating rate with much thicker leaves but ignited just as quickly as the single leaf fuels. This could be due to the low moisture content, but again, there could be some chemical composition differences (including the presence of or absence of a waxy leaf coating) between these fuels effecting the ignition time.

The wiregrass ignited almost instantaneously in $500^{\circ} \mathrm{C}$. This was a very thin fuel with a very high convective heat transfer coefficient and heating rate. Because it ignited so quickly at $500^{\circ} \mathrm{C}$, it was not tested in $600^{\circ} \mathrm{C}$.

\section{CONCLUSIONS}

Work on live fuel ignition processes is just beginning, but has already shown a number of responses that conflict with standard concepts of wildland fire behavior and which must be crucial to understanding fire spread in live vegetation canopies. First, water is present in most live fuels after ignition. This means that steep temperature gradients exist in fuel particles and that water vapor must be accounted for in live fuel combustion after ignition. Second, this also means that live particles are probably poorly approximated as thermally thin elements. Third, geometric properties of the live leaves (thickness, aspect ratios of surfaces) vary among species to the degree that they affect ignition independently of thermal characteristics. Finally, this work points out the gap in basic knowledge of convective heat transfer within the low range of Reynolds number common to flame impingement on live vegetation. 


\section{ACKNOWLEDGEMENTS}

This research was funded by the National Decision Support Center. The authors would like to thank Matt Jolly for sending us the fuels from Florida; Joey Chong and David Weise for the fuels from Riverside, CA; Tom Fletcher for the fuels from Utah; and Greg Askins from USF\&W for the wire grass from South Carolina.

\section{REFERENCES}

[1] Albini, F.A. "A model for fire spread in wildland fuels by radiation," Combustion Science and Technology 42: 229-258, 1985.

[2] Albini, F.A. "Wildland fire spread by radiation - a model including fuel cooling by natural convection," Combustion Science and Technology 45: 101-113, 1986.

[3] Albini, F.A. "Iterative solution of the radiation transport equations governing spread of fire in wildland fuel," Combustion, Explosion, and Shock Waves 32: 534-543, 1996.

[4] Butler, B.W., Finney, M.A., Andrews, P.L., and Albini, F.A. "A radiation-driven model for crown fire spread," Canadian Journal of Forest Research 34: 1588-1599, 2004.

[5] Catchpole, W.R., Catchpole, E.A., Tate, A.G., Butler, B., and Rothermel, R.C. "A model for the steady spread of fire through a homogeneous fuel bed," In 'Forest Fire Research and Wildland Fire Safety: Proceedings of IV International Conference on Forest Fire Research', 18-23 November 2002, Luso, Coimbra, Portugal. (Ed. DXViegas) (Millpress: Rotterdam, the Netherlands).

[6] Finney, M.A., Cohen, J.D., McAllister, S.S., and Jolly, W.M. "On the need for a theory of wildland fire spread,” International Journal of Wildland Fire 22(1):25-36, 2013.

[7] Yedinak, K.M., Cohen, J.D., Forthofer, J., and Finney, M.A. “An examination of flame shape related to convection heat transfer in deep-fuel beds," International Journal of Wildland Fire 19: 171-178, 2010.

[8] Niioka, T., Takahashi, M., and Izumikawa, M. "Gas-phase ignition of a solid fuel in a hot stagnation-point flow,” Symposium (International) on Combustion 18: 741-747, 1981.

[9] Wang, G.-G. and Tang, J.T. "Convective thermal ignition of an individual polymethylmethacrylate particle," Journal of Thermophysics and Heat Transfer 6(2): 333-340, 1992.

[10] Babrauskas, V. Ignition Handbook. Fire Science Publishers, Issaquah, WA 2003.

[11] DiBlasi, C., Portoricco, G., Borrelli, M., and Branca, C. "Oxidative degradation and ignition of loose-packed straw beds," Fuel 78: 1591-1598, 1999.

[12] Dimitrakopoulos, A.P., and Papaioannou, K.K. "Flammability assessment of Mediterranean forest fuels," Fire Technology 37:143-152, 2001.

[13] Jervis, F.X., Rein, G., Simeoni, A., and Torero, J.L. "The role of moisture in the burning of live and dead pine needles," Proceedings of the 6th International Seminar on Fire and Explosion Hazards, Leeds, April 2010.

[14] McAllister, S., Grenfell, I., Hadlow, A., Jolly, W.M., Finney, M., and Cohen, J. "Piloted ignition of live forest fuels," Fire Safety Journal 51: 133-142, 2012.

[15] Smith, S.G. "Effects of moisture on combustion characteristics of live California chaparral and Utah foliage,” M.S. Thesis, Brigham Young University, Provo, Utah, 2005.

[16] Xanthopoulos, G. and Wakimoto, R.H. "A time to ignition - temperature - moisture relationship for branches of three western conifers," Canadian Journal of Forest Research 23:253-258, 1993. 
[17] Engstrom, J.D., Butler, J.K., Smith, S.G., Baxter, L.L., Fletcher, T.H., and Weise, D.R. "Ignition behavior of live California chaparral leaves," Combustion Science and Technology 176 (9): 15771591, 2004.

[18] Fletcher, T.H., Pickett, B.M., Smith, S.G., Spittle, G.S., Woodhouse, M.M., Haake, E., and Weise, D.R. "Effects of moisture on ignition behavior of moist California chaparral and Utah leaves," Combustion Science and Technology 179(6): 1183-1203, 2007.

[19] Little, C.H.A. "Seasonal changes in carbohydrate and moisture content in needles of balsam fir (Abies balsamea)," Canadian Journal of Botany 48: 2021-2028, 1970.

[20] Kozlowski, T.T., and Clausen, J.J. "Changes in moisture contents and dry weight of buds and leaves of forest trees," Botanical Gazette 126(1): 20-26, 1965.

[21] Rothermel, R. C. “A mathematical model for predicting fire spread in wildland fuels." INT-115, USDA, Forest Service, Ogden, UT, 1972.

[22] Churchill, S.W. and Bernstein, M. "A correlating equation for forced convection from gases and liquids to a circular cylinder in crossflow," Journal of Heat Transfer 99: 300-306, 1977.

[23] Hilpert, R. Forsch. Geb. Ingenieurwes. 4:215, 1933.

[24] Incropera, F.P. and DeWitt, D.P. Introduction to Heat Transfer $4^{\text {th }}$ edition, John Wiley \& Sons, New York, 2002.

[25] Sparrow, E.M., Abraham, J.P., and Tong, J.C.K. "Archival correlations for average heat transfer coefficients for non-circular and circular cylinders and for spheres in cross-flow," International Journal of Heat and Mass Transfer 47: 5285-5296, 2004.

[26] Bergman, R. et al. Wood Handbook: Wood as an Engineering Material. Forest Products Laboratory. General Technical Report FPL-GTR-190. Madison, WI: U.S. Department of Agriculture, Forest Service, Forest Products Laboratory: 508 p. 2010.

[27] Anderson, H.E. "Predicting equilibrium moisture content of some foliar forest litter in the Northern Rocky Mountains," Intermountain Research Paper INT-429, USDA Forest Service, August 1990, 10pp. 